\title{
Dependence of productivity of an ear of barley as to amount of grains on periods of sowing and rates of seeding
}

A. Kufel

\section{Podolsk state agrarian-technical university}

The purpose. To determine influence of periods of sowing and seeding rates on amount of grains in an ear and productivity of grain of spring barley. Methods. Count, weighting, statistical. Results. It is fixed that with each subsequent sowing amount of grains in an ear decreased. The same is observed at increase of seeding rate. Action of probed factors on productivity of grain of spring barley is fixed. Level of productivity essentially dropped with each subsequent sowing. Conclusions. Increase of seeding rate results in significant drop of productivity at periods of sowing on 15.03. and 25.03. At sowing on 05.04. essential variance is fixed between values of productivity for seeding rates 350 and 400 pieces $/ \mathrm{m}$. In next periods of sowing differences between productivity of probed seeding rates were negligible.

Key words: barley, periods of sowing, seeding rate, amount of grains, elements of yield, stages of organogenesis.

Introduction. Number of grains in the ear is an important indicator - is one of the elements of the structure of the crop. In cereals the rudiments of the axial structure of a complex inflorescence - spike core formed on the second and third stages of organogenesis. The delay of the II stage (low temperature, short daylight hours) increases the segments axis of the spike, and therefore the number of ears and back, accelerate development (long day, high temperatures, low light intensity) leads to a reduction in the number of laid meromes [1, 2, 3, 4, 5].

Analysis of recent researches. Sowing affects the duration of II and III stages of organogenesis, which coincide with the phase of tillering of plants. On early sowing tillering phase begins earlier and lasts longer because access to the tube at different plants sowing begins in almost the same period, with a slight difference in days [6-8].

In number of grains in the ear can also affect technological factors such as seeding rate of seeds. In the studies, Laman N.A., Stasenko N.N., Kaller S.A. found that there is a significant difference in all elements of crop structure depending on the strength of coenotical interaction in crops. The amounts of grain in the ear in a double row barley varieties Minsk ranged from 12 to 25 pcs., based on crops density [9].

Materials and methods. Researches were conducted on the experimental field of scientific and production center "Podillia" PSATU, during the 2014-2016 years. Crops of spring barley of varieties Syebastyan and Eksployer were the objects of the research. Factor A - sowing: 15.03., 25.03., 05.04., 15.04., 25.04., factor B - seeding rate: 300,350 and $400 \mathrm{~s} . / \mathrm{m}^{2}$. Number of grains in the ear and yield records were set by conventional techniques highlighted by V.F.Moyseycheno., V.O.Yeschenko.

The results of the experimental data were calculated using Duncan test and correlation analysis [10].

The results of the researches. In the researches it was found that indicator of the number grains in the ear plant of spring barley varieties Syebastyan was within 17,1- 21,7 pc. and plants varieties Eksployer - 16,8 - 21,5 pc. (Table. 1). 
Table 1. Number of grains of spring barley spike, depending on the impact of sowing and seeding rate, pc., (average for the 2014-16 years.)

\begin{tabular}{|c|c|c|c|c|c|c|}
\hline \multirow{4}{*}{$\begin{array}{l}\text { Terms of } \\
\text { sowing }\end{array}$} & \multicolumn{6}{|c|}{ Varieties } \\
\hline & \multicolumn{3}{|c|}{ Syebastyan } & \multicolumn{3}{|c|}{ Eksployer } \\
\hline & \multicolumn{6}{|c|}{ Seeding rate, $\mathrm{pc} . / \mathrm{m}^{2}$} \\
\hline & 300 & 350 & 400 & 300 & 350 & 400 \\
\hline 15.03. & 21,7 & 21,1 & 20,6 & 21,5 & 20,9 & 20,3 \\
\hline 25.03. & 21,1 & 20,3 & 19,6 & 20,7 & 20,0 & 19,3 \\
\hline 05.04. & 19,9 & 19,4 & 18,9 & 19,7 & 19,3 & 18,7 \\
\hline 15.04. & 18,7 & 18,2 & 17,7 & 19,0 & 18,4 & 17,9 \\
\hline 25.04 & 17,7 & 17,4 & 17,1 & 17,8 & 17,2 & 16,8 \\
\hline
\end{tabular}

The analysis of the results, based on Duncan test indicates that sowing affect the amount of grain in the ear plant of spring barley. These different sowing are in separate homogeneous group, indicating a significant difference between them. The greatest amount of grain received in the first term sowing plants and found that the number of grains in the ear decreases with each successive sowing. Thus, the average years of research, the value of the number of grains of plant varieties Syebastyan, an average of the experiment were: 20,$9 ; 20,2 ; 19,3 ; 18,1,17,4$ pc., Eksployer: 20,7; 19,9; 19,1; 18,4; 17,3 pc. according to sowing 15.03., 25.03., 05.04., 15.04., 25.04. The established pattern was observed annually.

Number of grains in the ear also depends on the seeding rules. This figure is the highest seeding rate by $300 \mathrm{~s} . / \mathrm{m}^{l}$ and an average of $19,8 \mathrm{pc}$. in Syebastyan variety and $19,7 \mathrm{pc}$. of plants in Eksployer variety. It has been stablished a significant reduction in the number of spike grains with increasing of seeding rate of seeds. By increasing of seeding rate of studied varieties $50 \mathrm{~s} . / \mathrm{m}^{2}$ number of grains it was decreased by 0,6 pc. and it was, Syebastyan - 19,2 pieces. Eksployer - 19,1 pc. By significantly reducing the number of grains resulted from sowing seed rate of $400 \mathrm{~s} . / \mathrm{m}^{2}$ compared to the values of seeding rate $350 \mathrm{~s} . / \mathrm{m}$. The difference was, for a variety Syebastyan $-0,7$ pc., in variety Eksployer - 0,8 pc. Between seeding values of 300 and $400 \mathrm{~s} . / \mathrm{m}^{2}$ difference is $1,3 \mathrm{pcs} . / \mathrm{m}^{\prime}$ and $1,4 \mathrm{pcs} . / \mathrm{m}^{2}$.

Investigated factors including sowing rate have done a significant impact on grain yield of spring barley. The highest grain yield was obtained in the first term of sowing, on average, it amounted to 7,59 $\mathrm{t} /$ ha of Syebastyan variety and 7,81 t/ha of Eksployer variety. For the second and subsequent sowing yield gradually decreased. With the sowing of 25.04. yield of Syebastyan variety was $6,70 \mathrm{t} / \mathrm{ha}$ and 6,60 $\mathrm{t} / \mathrm{ha}$ of Ekspoloyer variety, 05.04. - 5,42 t/ha; $5,45 \mathrm{t} / \mathrm{ha} ; 15.04$. $-4,32 \mathrm{t} / \mathrm{ha} ; 4,36 \mathrm{t} / \mathrm{ha} ; 25.04 .-3,29 \mathrm{t} / \mathrm{ha}$; 3,09 t/ha respectively.

Grains yield of spring barley seed according to seeding rate $300 \mathrm{~s} . / \mathrm{m}^{2}, 350 \mathrm{~s} . / \mathrm{m}^{2}, 400 \mathrm{~s} . / \mathrm{m}^{2}$, the average was as follows: 5,$64 ; 5,48 ; 5,28 \mathrm{t} /$ ha and 5,65 of Syebastyan variety; 5,$48 ; 5,26 \mathrm{t} / \mathrm{ha}$ of seed of Eksployer variety. Seeding rate was influential factor of technology on productivity of barley for early sowing. When sowing 5.04 it was found only difference between the values of seeding rate $350-400 \mathrm{~s} . / \mathrm{m}$. By sowing on the 15 and 25 of April between data of studied norms of seeding rate significant difference is not set. 


\section{Conclusions}

1. It has been established that changes in the number of grains of the influence factor $A$ is essential for the Syebastyan variety from 17,4 to 20,9 pc., for variety of Eksployer - from 17,3 to $20,7 \mathrm{pc}$.

2. Change of the number of grains of the factors is from 18,5 to $19,8 \mathrm{pc}$. in Syebastyan variety and Eksployer variety is from 18,3 to $19,7 \mathrm{pc}$.

\section{References}

1. N. Laman. N. Yanushkevich, K.I. Harec Potential consumption of cereals: Technological aspects of realisation.-Mn.: Science and technology, 1987. - 224 p. (p. 44-51).

2. Gorash A. S., Bhulan S. P. Spring Barley / A. S. Gorash, S. P. Hulak. - PE "Medobory-2006", 2013. -64 p. (22)

3. Kennedy S. P., Spink J. H., Binghaml. J., Identifying constraints to increasing yield potential in barley / S. P. Kennedy, J. H. Spink, I. J. Bingham // SAC Postgraduate Research Conference, April 6th 2011 Edinburgh, UK.

4. Noworolnik K. Morphological characters, plant phenology and yield of spring barley (Hordeumsativum L.) Depending on cultivar properties and sowing date / K. Noworolnik // Actaagrobotanica Vol. 65 (2). - 2012. - C. 171-176

5. Noworolnik K. Kareem kniesel and protein content in grain of brewery cultivars of barley depending on sowing rate / K. Noworolnik // Fragm. Agron.,2008. - 1(97): C - 278-287. (in Polish)

6. TrnkM., Dubrovský M., Žalud Z. Climate change impacts and adaptation strategies in spring barley production in the Czech Republic // Springer Nature, may 2004, volume 64, Issue 1, P. 227-225

7. Gorash A. S., Klymychyna R. I. Realization of the potential productivity of elements of structure of yield of winter barley / A. S. Gorash, R.I. Klymychyna // Bulletin of agricultural science. - 2015. - No. 7. S. 27-30.141

8. Gorash A. S., Klymychyna R. I. Peculiarities of formation of yield structure of spring barley / A. S. Gorash, I. Klymychyna R. // the Latest agricultural technologies. - 2014. №1(2). S. 4-11

9. N.. Laman, N. N. Stasenko, S. A. Kaller Biological potential of barley: lodging resistance and productivity. - Mn.: Science and technology, 1984. -216 p. (p. 140)

10. Moiseichenko, F. V.,Yeshchenko V. A. Fundamentals of scientific research in agronomy: a textbook. - K.: Higher school, 1994.-334c. 